\title{
Where is the Kit Fox?
}

\author{
By R. D. SYMONS, Fort St. John, B.C.
}

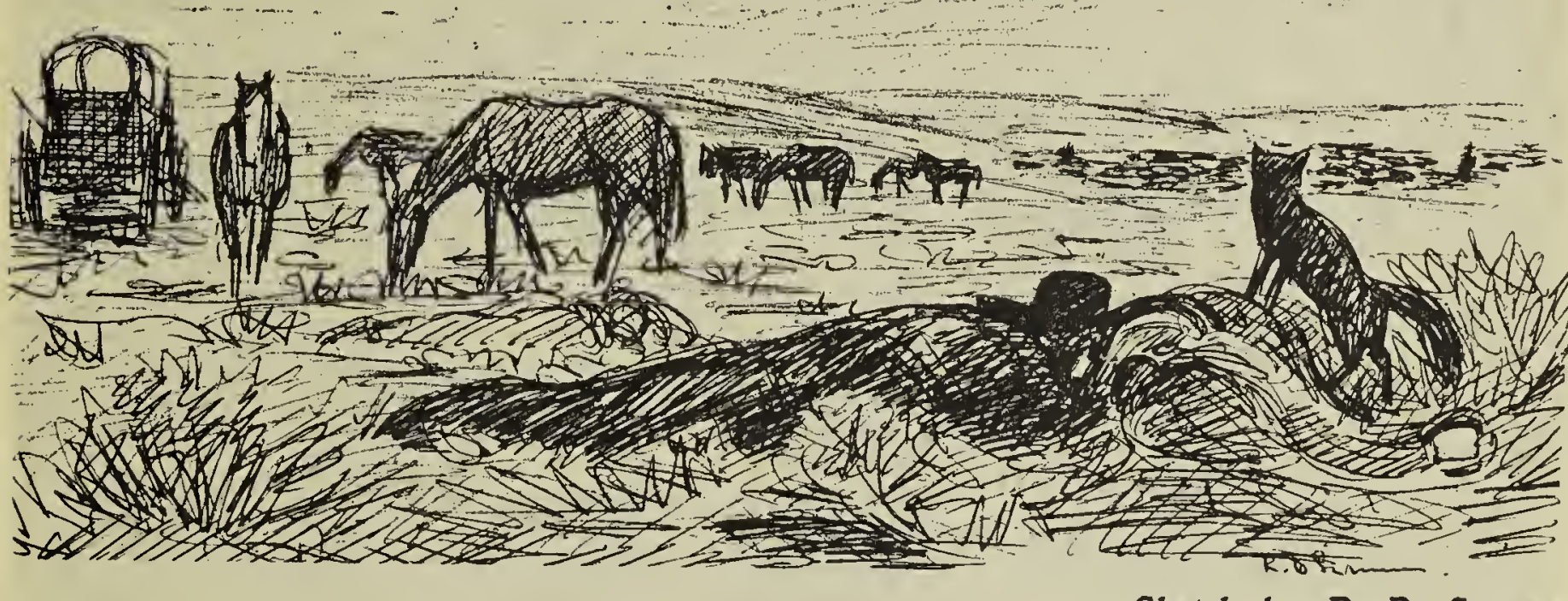

Whether the Kit Fox still exists on the Canadian prairies is a maiter for much interesting conjecture. Although it has not been reported for years, there is a possibility that the Kit Fox is not extinct. It is one of the shyest of creatures and even when it was relatively abundant, it was rarely if ever seen by day. In this respect it is like some of its desert fox relations, for example the desert fox of Arabia and Mesopotamia. My brother-in-law, Major Onslow, who spent many years from the mountains of Kurdistan to the delta of the Tigris, tells me that he only saw these animals on night manoeuvres. In the same way I remember that in the days before World War I, we often had these little foxes around our camps on the prairies, and would occasionally catch glimpses of one about the time we rolled out of our blankets in the sage-brush as the first faint grey of dawn showed in the eastern sky. But when we went to catch our horses and prepare for the day's work we knew the fox or foxes had paid us more than a brief visit. Saddle stirrups would be chewed to a pulp, corners of saddle blankets torn, and halters and wagon harness well tooth-marked or even reduced to a collection of iron buckles. I remember that a friend of mine had his boots chewed although he had put them half under his blankets. It seemed that anything sweaty (like a hat brim or the face of a horse collar) was particularly favoured by the little pests, who were no doubt in need of salt.
Why are the Kit Foxes seen no more? Have they been exterminated, and if so, how and why? They rarely seemed to bother poultry, they were too small to menace lambs or calves, and we know of no persistent enemy. Probably Golden Eagles picked up an occasional one. It is also possible that coyotes sometimes killed them, or farm dogs, but the Kit Fox would usually be much the fleeter animal. Ranchers, cowboys and farmers got the occasional lucky shot at them, but not many seemed to have been taken that way. Since their pelts were of no great value, Kit Foxes were only accidentally caught in traps.

One well known tileory is that they were poisoned by sheep and cattle ranchers who put out bait for lobos and coyotes. But it is hard to believe that any animal of the Order Canidae, an order renowned for cunning and brains, would be so foolish as to commit complete racial suicide by persisting in taking poison bait. Our combined and devilishly clever use of modern poison methods can never be more than partially successful in eradicating wolves. And coyotes, I was told when last in Saskatchewan, have again appeared in areas thought to be $100 \%$ free of them. Here in the Peace River Country, poison has been used extensively by the Game Department of B.C. against lobos and coyotes, but there are still both these animals to be seen and heard. Individuals surviving from a pack or family that starts to feed on a poisoned carcass will thereafter avoid any food they have 


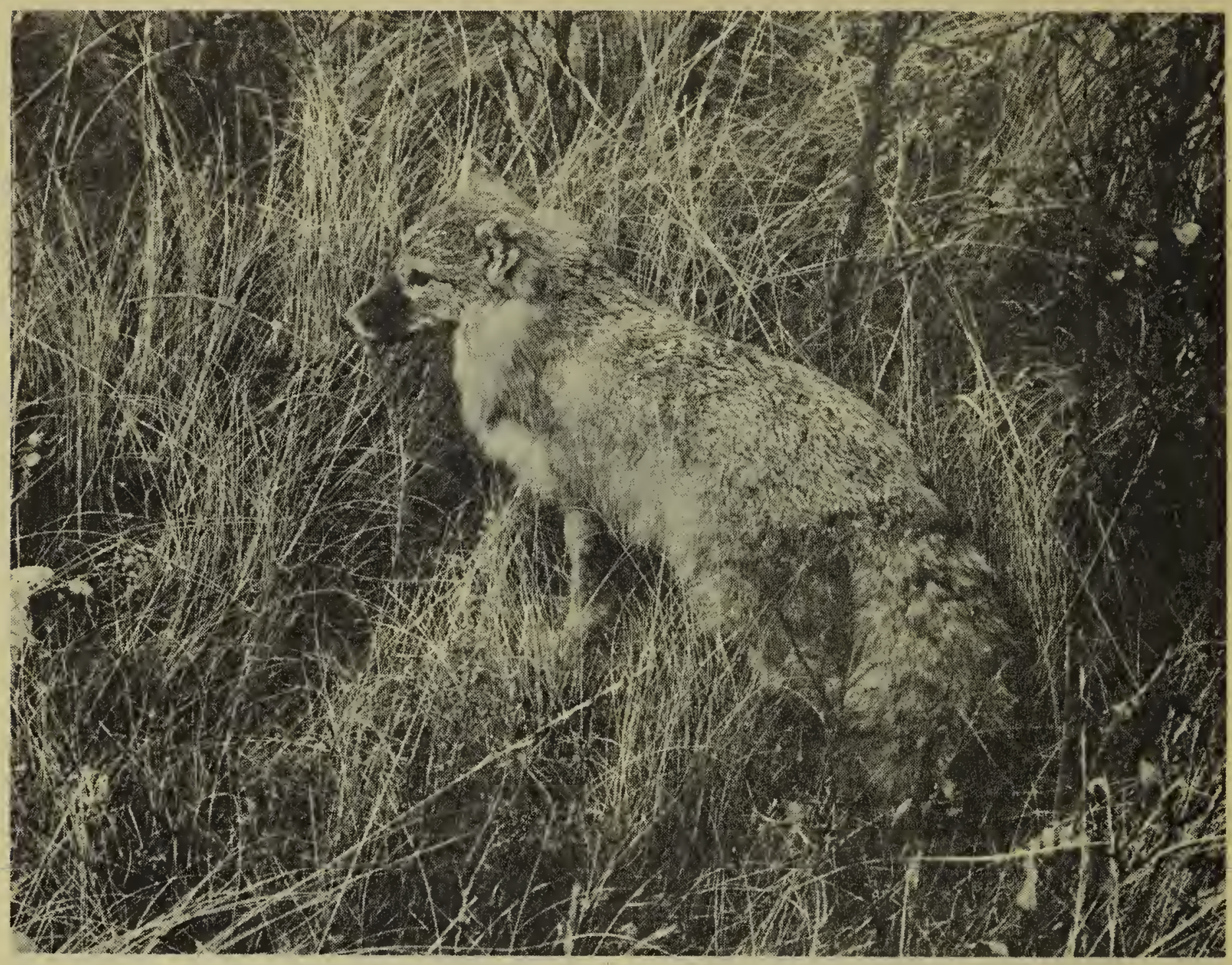

not killed themselves. As I write, the snow is the deepest we have seen it here, and the winter has been the longest and most severe. A cow which died in January and was hauled into the bush is still untouched except by Ravens and Magpies, although every day I see the track of a coyote in the bush, and the other night I heard a timber wolf.

The Dingo is another animal which has survived, all attempts to exterminate it. These Australian wild dogs have been hunted, shot and poisoned for over 150 years, but they still persist, and the Dingo hunters know that only a percentage can be poisoned. If, then, the Kit Fox of Saskatchewan was completely annihilated by poison not set for him, he was certainly no credit to the canny dog tribe.

What records there are for our prairie Kit Fox in Montana and the Dakotas in recent years I do not know; I believe that there, too, they are supposed to be non-existent. But one should draw no hasty conclusion from the fact that no one seems to have seen a Kit Fox in the last thirty years. The southern range land covers an immense, sparely settled area, and within that area are many half-breeds and Indians who might well have seen, and even killed, a Kit Fox without reporting it. And one argument still remains in favour of the Kit Fox's still inhabiting the broken table land and grey sage flats westward from Wood Mountain. Since these animals were mostly seen at night and their presence known by the condition of the saddles and bridles in the morning, they were only evident to people active at night and in the early morning. In the early days, round-up wagons were on the move from spring to fall. Riders got up in the morning when it was hardly light. Some took turns at "night guard," and others came off their circles long after the sun had set. These men of the range were observant men. No city man, driving to his office at nine, no farmer clanking to the barn with his milk pails, could see or care about one-tenth of what the horsemen of the plains saw. And only they left equipment upon which the Kit Fox could leave his mark.

With the fencing of the range, the old life largely disappeared. The cowboy of today usually sleeps and eats under a roof, and cattle are 
penned for the night in corrals. Only the sheep herders live much as they used to, but there is now only one where fifty years ago there were perhaps a hundred. However, in any attempt to find out if these foxes still persist in some remote corner, every cowboy, sheep-herder, and Indian should be asked for information. No Kit Foxes having been seen or shot for years alarms me, but does not prove that they no longer exist.

Editor's Note: A letter from Mr. S. A. Mann of Skull Creek tells how years ago kit foxes were very numerous and easy to trap or poison. He says that they were trusting animals and came in around the farm build. ings. He has not seen one since about 1905.

Mr. Don Kirk, P.F.R.A., Regina, is not so sure that the kit fox is extinct in Saskatchewan. He thinks he saw one last summer on the south watershed of the Cypress Hills near Cypress Lake. He wrote several letters to old timers in the area but they were guarded in their comments. Mr. T. E. Fordice says, "We have not seen any kit fox although they used to be here and it is rumoured that there are some near." Mr. H. I. Wallace says, "I believe one was seen near Battle Creek in 1954."

The last authentic report we have of a kit fox seen in Saskatchewan comes from the Museum's files. This was a kit fox trapped in 1927 near Ravenscrag and donated to the Museum where it has been mounted and preserved.

\section{The Ups and Downs of Game at Crescent Lake}

\section{By. K. E. BAINES}

The following observations are based on information taken from my grandfather's diary commenced in August 1883 and later from $m y$ father's diary commencing in 1917both of which are in my possession. Besides these, I have personal memories dating from about 1910 from my contacts with both the above men. The area concerned is in the immediate vicinity of Crescent Lake which is my birthplace and still very dear to me, even though I left it some twenty years ago. Crescent Lake is 16 miles south of Yorkton.

Crescent Lake is a shallow body of water which in dry cycles dries up to nothing but a meadow of grass and weeds. In 1883 it was full of water. It was completely dry about 1897 and again in 1938. It was full to overflowing in 1919 and is again high in 1956. The amount of water in the lake, of course, reflects the wet and dry cycles of the district and has a definite bearing on many species of game.

I will deal with game animals first. In 1883 the prairie was covered with buffalo bones, the last of these large animals having been disposed of only a few years before. Almost as conspicuous as the buffalo bones were the large antlers of elk, and I can still remember seeing lots of these in some of my hikes to the less-frequented spots. Elk must have been very numerous some years previous and they seem to have disappeared about the same time as the buffala. They were probably just an extension of the great foothill herds and for some unknown reason they retired to that area and to a few isolated spots such as the Moose Mountains and Beaver Hills, and have never been away from these places since to any extent. Man was surely not a factor here; otherwise, elk could never have made a comeback-even with protection.

Mule Deer or Blacktails, as they were locally known, were fairly common in 1883. They were the only deer. They became very scare and the season was closed about 1910. About this time Whitetail, or Virginia Deer, appeared in quantity and at practically the same time the Mule Deer became scarcer, disappearing altogether about 1928. The Whitetail became more common until there was insufficient pasture and many died during several springs in the 1920 's and even later. Again the Mule Deer came from the west and has withdrawn in that direction, while the Whitetail came from the east and appears to be pushing farther west.

Rabbits and Jackrabbits have had their usual ups and downs, but I am beginning to wonder just what is happening here, as they have not been numerous for ten or fifteen years now. Could the use of 2-4-D be having an adverse effect on the rabbit population?

Foxes were numerous in 1883, but coyotes did not appear for some years. When they did appear, the fox nearly disappeared and has 